\title{
Towards a reassessment of Douglas Young
}

Motivation and his Aristophanic translations

\section{Bill Findlay}

\section{(2) OpenEdition}

\section{Journals}

Electronic version

URL: http://journals.openedition.org/etudesecossaises/161

DOI: 10.4000/etudesecossaises.161

ISSN: 1969-6337

\section{Publisher}

UGA Éditions/Université Grenoble Alpes

\section{Printed version}

Date of publication: 31 March 2005

Number of pages: $175-186$

ISBN: 2-84310-061-5

ISSN: 1240-1439

\section{Electronic reference}

Bill Findlay, "Towards a reassessment of Douglas Young », Études écossaises [Online], 10 | 2005,

Online since 31 March 2005, connection on 08 September 2020. URL : http://journals.openedition.org/ etudesecossaises/161; DOI : https://doi.org/10.4000/etudesecossaises.161 


\title{
Towards a reassessment of Douglas Young
}

\author{
Motivation and his Aristophanic translations
}

BILl FINDLAY

Queen Margaret University College, Edinburgh.

1. See Lorna Hardwick, "Classical Theatre in Modern Scotland

- A Democratic Stage?», Hardwick \& Gillespie, p. $1-13$

2. Unpublished but discussed in: Ian Brown and Ceri Sherlock,

«Antigone: A Scots/Welsh Experience of Mythical and Theatrical

Translation ", in Unity in Diversity?: Current Trends in Translation Studies, ed. by Lynne Bowker and others, Manchester, St Jerome, 1998,

p. 25-37; Ian Brown

John Ramage and Ceri Sherlock, «Scots and Welsh Theatrical Translation and

Theatrical Languages », IJoST: International Journal of Scottish Theatre, $1: 2,2000,<$ http:// arts.qmuc.ac.uk/ijost $>$ 3. (Young, $1958 \& 1959$ ) The Burdies will be included in John Corbett and Bill Findlay, eds. Serving Twa Maisters: An Anthology of Scots Translations of Classic Plays, Glasgow, Association for Scottish Literary Studies, forthcoming, 2005.
In recent years Greek classical drama has achieved a new profile in Scottish theatre through a surge of translations and versions done into English or Scots, mostly by prominent playwrights, and created from Greek or from other languages and plays through which the Greek originals have been mediated $^{1}$. Two of the most significant examples are Liz Lochhead's Scots version, «after Euripides », of Medea (2000), and Edwin Morgan's Scots translation of Racine's Phaedra (2000). The former originated as part of a triple bill collectively titled Greeks, which included versions of Electra by Tom McGrath and of Oedipus by David Greig. The most recent of a number of other examples is, at time of writing, Peter Arnott's House of Murders (2004), a reworking of Aeschylus's Oresteia. Lochhead's and Morgan's choice of Scots as their medium had precursors of sorts, not just in relation to their earlier translations of, respectively, Molière's Tartuffe (1986) and Edmond Rostand's Cyrano de Bergerac (1992), but in other renderings of Greek classics into Scots: Bill Dunlop's version of Klytemnestra's Bairns (1993), taken from the Oresteia; Ian Brown's version of Antigone (1969), based on the plays by Sophocles and Anouilh ${ }^{2}$; and Douglas Young's translations of two of Aristophanes'plays, The Puddocks (1958) and The Burdies (1959; 1966) ${ }^{3}$.

The Puddocks was first staged by «The Reid Gouns», a StAndrews University student group, who performed it at the Byre Theatre in the town in February 1958. Later that year, an amateur group, "The Sporranslitters», staged an open-air production at the Braidburn Theatre in Edinburgh as an Edinburgh Festival Fringe event. The Burdies was premiered in 1959, again by «The Reid Gouns », but in the Cathedral Hall, Albany Street, Edinburgh, at the Edinburgh Festival Fringe. It was subsequently given full professional performance in 1966, when the Royal Lyceum Theatre Company, Edinburgh, in its inaugural season, made the translation the vehicle for 
4. Contemporaneously, Robert Garioch

translated into Scots two sixteenth-century Latin tragedies by George Buchanan drawing on Greek classical sources; however, though Garioch's translations were published in 1959 they were not staged. 5. J. Derrick McClure, "The Puddocks and The Burdies "by Aristophanes and Douglas Young"", (Findlay, p. 215-230, reference, p. 215-216. Hardwick, «Classical Theatre in Modern Scotland-A Democratic Stage?», p. 4, reports that Ronald Knox gave a paper on Douglas Young at the 100th anniversary conference of the

Classical Association of Scotland in April 2002 which included discussion of his translations of Aristophanes. See also note 29 below.

6. McClure, «Scots in Dialogue: Some Uses and Implications " (McLure, 1993, p. 148.) the company's first main-programme contribution to the Edinburgh International Festival. This prestigious production, featuring a large cast, along with a chorus of singers and a band of musicians, drew on the talents of many of the best-known names in Scottish theatre, with actor Tom Fleming as director, and, in the cast, luminaries such as Duncan Macrae, Fulton Mackay, Lennox Milne, Jean Taylor Smith, Callum Mill, and a youthful Brian Cox.

The translation of foreign drama into Scots is essentially a modern development that commenced in the 1940 s with Robert Kemp's Let Wives Tak Tent (L'École des femmes), added to by him, in 1955, with another Molière, The Laird o'Grippy (L'Avare) (Kemp, 1983, 1987). Young was the first to follow up on Kemp's example, and to him must go the credit for initiating translation of Greek classical drama into Scots ${ }^{4}$. Young's reputation has tended to be based on his work as a poet and polyglot translator of poetry; the equal or greater significance of his contribution as an early translator of drama into Scots has only very recently, in the form of an essay by J. Derrick McClure published in 2004, begun to receive the attention previously given to that other work. McClure offers an appreciative analysis of the use of Scots in the two translated plays, helpfully opining that Young's «most substantial exercises in translation [...] are not in the field of lyric but of dramatic poetry». He makes brief mention of the question of Young's reasons for embarking on those translation, noting that « $[\mathrm{t}]$ he translation of literature is an act in which individual motives are liable to play an important role ${ }^{5} »$. Rather than offer further analysis of Young's stage Scots, the discussion here will pick up on that comment by McClure in exploring the motives informing The Puddocks and The Burdies by way of a contribution to encouraging a reorientation in study of Young that takes greater account within his oeuvre of his Scots translations of Greek drama and the considerations shaping them. At the back of the discussion, too, will be awareness of a more general observation made by McClure in a 1983 essay on the use of Scots in dialogue: «the mere fact of writing in a tongue other than the official standard [...] implies some conscious decision on the part of the author; and his possible motivation, and the mode in which it emerges in his work, has been investigated much less extensively ${ }^{6} »$. In that McClure has offered an initial analysis of Young's «mode» in his 
Aristophanic translations, the following will offer some investigation of his «motivation».

When Young made his play translations he was a lecturer in Classics at St Andrews University. The immediate reason for the translations was to satisfy requests from his students. In a foreword to the published script of The Puddocks (Puddocks, p. vi). he acknowledged «Mr Gordon Stirling Maxwell, a member of the Honours Classics class, at whose request I undertook the translation in July, 1957», and he stated in his verseaddress, «Epilogue (Spoken on the final nicht [of the student production], 28th February, 1958)»:

But here's the richt Initiator,

that set on fuit this play sae fine,

Gordon Maxwell frae Corstorphine.

It was his idea tae dae in Lallans

this auld Greek play; he waled the callans

and lassies here, wi rowth o talents.

Gordon produced it, gleg and slee. (Puddocks, p. 55)

Young recorded: «that play [The Puddocks] having met with some acceptance, the group of students concerned, calling themselves «The Reid Gouns», then asked for a version of The Burdies in time for the Edinburgh International Festival of 1959» (Burdies, p. iii).

However, one can go beyond these immediate instigations to locate a wider range of motivational factors coalescing to inform Young's translations of Aristophanes into Scots. What these were can be identified in part through a biographical résumé. Douglas Young was born in Fife in 1913 and died in the USA in 1973. His father worked in India and he spent his early years there before becoming a boarder at Merchiston Castle School in Edinburgh. He went on to study Classics at St Andrews University, which he chose, in preference to the Oxbridge route urged on him by his schoolmasters, out of «a sort of Nationalist instinct ${ }^{7}$ ». That «instinct» became for him a lifelong dedication as a cultural-political activist of left-wing

7. (Young, 1950, p. 55). He also gives an account, on p. 55-66, of the origins of his Scottish nationalism, his involvement in parliamentary elections for the Scottish National Party, and his trials and imprisonment for refusing conscription sympathies to the cause of Scottish independence. As well as standing as a parliamentary candidate for the Scottish National Party, he served as Chairman of the party for a period. He also closely aligned himself with the Scottish Renaissance literary movement initiated by Hugh MacDiarmid in the 1920 s, and followed MacDiarmid in his vigorous advocacy of the Scots language. He became one of the most prominent 
writers associated with the second wave of the Scottish Renaissance that emerged in the late1930s and 1940s, to which he made significant contributions as a polemicist, poet, critic and translator; indeed, a profile of him in The Scots Review in 1947 stated: "Still in his early thirties Young is the acknowledged pillar of the Renaissance ${ }^{8} »$. After St Andrews University, Young continued his studies at Oxford University, then took up a Classics post at Aberdeen University in 1938. During World War II he refused conscription out of nationalist principle and served two terms of imprisonment. While he was in Barlinnie Prison, his first collection of Scots poems and verse translations from a variety of languages, Auntran Blads, 1943, was seen through the press by friends; his second, $A$ Braird o Thristles, followed in 1947 . The publicity attracted by his two trials and prison sentences caused him employment difficulties but he eventually secured a post at St Andrews University, where he remained from the late 1940s until 1968 when he took up a Classics chair, first in Canada and then in the USA. In a memorial volume published after his death, one tribute concluded: «He was a polymath [...] with a fantastically well-stored mind, enriched by the widest reading, constant travel, and contacts with people of all lands and of all conditions ${ }^{9} »$.

As regards Young's Scots translations of Aristophanes, one can see from this summary of his life that informing factors are likely to include, centrally, his politico-cultural nationalism, and, flowing from this, his commitment to the ideals of the Scottish Renaissance and promotion of the Scots tongue, and service to these through his linguistic scholarship as both a polyglot and a Classicist. The importance of these factors is confirmed by Hugh MacDiarmid's foreword to Young's Auntran Blads, where, in discussing what he refers to as the «Scottish Renaissance movement» and Young's place within it, MacDiarmid singles out as defining elements, as instanced by Young's

8. «Scots Whae Hae $\mathrm{n}^{\circ} 13$ - Douglas Young», [anon.], The Scots Review, 8:1 (April 1947), p. 10. 9. A Clear Voice: Douglas Young, poet and polymath, [no ed.], (Loanhead: Macdonald, [n.d.;? 1974]), p. 31.

10. «Foreword by Hugh MacDiarmid» (Young, 1943, p. 5) work: "a revived Scottish Nationalism», «a thorough-going critical revaluation of the Scottish past in all its aspects, and a new insistence on the Scots Lallans language», «wide-ranging linguistic and scholarly interests», and «internationalism ${ }^{10} »$.

What MacDiarmid means here by «internationalism » overlaps with his stress on «linguistic and scholarly interests", and can be illuminated with reference to a statement he made about the Scottish Renaissance poets of Young's generation: 
These new Scots poets [...] are internationalists in their literary sympathies [...] and have translated into Scots a great body of poetry from German, French, Russian, and other European languages [...] [These] healthy intromissions with the whole range of European literature [...] have been a notable feature of our recent literary history, like a veritable return to the Good Europeanism of our mediaeval ancestors ${ }^{11}$.

In 1940 MacDiarmid invited Young and other poets to visit him at his then home on the Shetland island of Whalsay. In response Young wrote a verse-letter in Scots, «Letter to Hugh MacDiarmid, 1940», in which he salutes the linguistic internationalism of MacDiarmid's work (MacDiarmid having translated or adapted poetry into Scots from a number of languages) :

Icelandic and Scots and German and whiles Greek, Provençal, Chinese, and the lave that ye speak, - aa your galvanic energie fizzan and sputteran ${ }^{12}$.

Young's verse-letter embodies this same impulse that he admired in MacDiarmid, admixing the Scots with lines of Gaelic, Greek, French, German, Latin, and Russian. We see this polyglot practice at work, too, in his Auntran Blads, which has poetry by him written in Scots, English, Greek, Latin, French, and German; poems by Burns translated into Greek; and translations into Scots of poems from Gaelic, Greek, Latin, Italian, French, German, Lithuanian, Chinese, and Russian (Young, 1943). His second collection, A Braird o Thristles, features poetry in Scots, English, and French; and translations of poetry into Scots from Gaelic, Welsh, Lithuanian, French, Hebrew, Russian, German, Greek, and Chinese (Young, 1947). As McClure has noted, Young's work «contains the widest range of translations in the oeuvre of any single writer in recent

11. Hugh MacDiarmid, ed., The Golden Treasury of Scottish Poetry London, Macmillan, 1946; repr. 1948), p. xxiv

12. D. Young, «Letter to Hugh MacDiarmid, 1940 » [and

accompanying author's notes] (Lindsay, 1945 , p. 25-29. The quotation is on p. 27).

13. J.D. McClure,

«Three Translations by Douglas Young», Macafee \& Macleod, p. 203. Scots poetry ${ }^{13}{ }^{\text {». }}$

The fruits of his multilingualism served a nationalist purpose in reasserting Scotland's independent links with the world and demonstrating the potentialities that still resided in Scots as a literary medium capable of translating effectively a variety of languages and writerly styles. Kurt Wittig has suggested that, «though there is [in Young's case] something Goliardic in it, all this is also reminiscent of the Scots humanists of the sixteenth century, and it betokens a genuine effort to establish cross-relations with other cultures» (Wittig, 1958, p. 298). In other words, Young's polyglot translation work also allowed a 
14. Young's Chasing An Ancient Greek is testimony to his multilingual skills and his «Good Europeanism». That book also demonstrates his appreciation of sixteenth-centur Scottish humanism and its «Good Europeanism»: (ch. 5, p. 26-34) is given over to discussion of Henry Scrymger, a Dundonian and

Hellenist, whom Young places within a larger context of Scottish

Renaissance humanists who studied and held professorial posts at Continental European universities.

15. Tom Hubbard,

«Reintegrated Scots:

The Post-MacDiarmid Makars» (Craigs, 1987, p. 181). For Garioch's translations of

Buchanan's Latin tragedies, see note 4 above.

16. Bill Findlay, «Robert Garioch's Jephthah and The Baptist: Why he considered it "My Favourite Work"”, Scottish Literary Journal, 25: 2, November 1998, p. $45-66$.

17. William [Bill]

Findlay, «Diaskeuasts of the Omnific Word Cencrastus, 23, June/ August 1986, p. 48-52. 18. The «Editor's Introduction », by R.L.C. Lorimer, (Lorrimer, 1983) confirms the long gestation of the translation and the linguistic nationalism informing his father's wish «to resuscitate and recreate Scots prose» (p. xiv-xv).

19. See A Clear Voice, p. 20. It is mentioned there, too, that Lorimer "had much sympathy also with his [Young's] nationalist views ». reconnection with an earlier period of internationalism («the Good Europeanism of our mediaeval ancestors", in MacDiarmid's phrasing) ${ }^{14}$. This had a special significance in relation to Young's translation of the Classics into Scots, as hinted at in Wittig's reference to Scottish humanism. In discussing what he terms «the Post-MacDiarmid Makars», Tom Hubbard remarks of Young's fellow Renaissance poet Robert Garioch's translations into Scots of Latin plays by George Buchanan that, "together with Douglas Young's versions of Aristophanes [...] they reassert what Dr George Davie has called «the vernacular basis of Scottish humanism», the onceproud relationship of mastery of the classics to mastery of Scots ${ }^{15}$ ». This tradition of Scottish vernacular humanism and its influence on Robert Garioch's motivation in translating into Scots Buchanan's two sixteenth-century Latin plays has been discussed elsewhere at length by me ${ }^{16}$. Suffice to say here that the tradition entailed translation of Classical texts into Scots as a challenging means of "stretching» and enlarging the language, and of enhancing its status through association with prestige literature. It was a tradition with its roots in the sixteenth century but it had become broken by the twentieth century. Its revival was one aspect of the more general recovery of and reconnection with Scotland's cultural past associated with the MacDiarmid-led Scottish Renaissance.

I have argued elsewhere that Robert Garioch, Douglas Young, and W. L. Lorimer all sought to revive Scottish vernacular humanism in their respective translations from Classical languages ${ }^{17}$. Lorimer translated from the original Greek The New Testament in Scots which, though not published till 1983, can be considered, because of its decades of gestation, as a late fruit of the MacDiarmid-led Scottish Renaissance ${ }^{18}$. Lorimer, like Young, was a professional Classicist and a Scots language enthusiast with nationalist sympathies. He was a long-standing colleague of Young's at St Andrews University and was instrumental, as head of the Classics department, in gaining Young employment there after his imprisonment in the $1940 \mathrm{~s}^{19}$. In translating The Puddocks and The Burdies Young acknowledged his indebtedness to Lorimer «with regard to matters of both Scots and Greek usage» (Puddocks, p. vi) \& (Burdies, p. v). Lorimer, too, was a polyglot, and drew on his command of several languages in reading foreign translations of the New Testament to assist him in preparing his Scots translation. In this respect, one notes 
as well that Robert Garioch, in addition to his translations of Buchanan's Latin plays, translated into Scots a substantial body of poetry from different languages. This again confirms the complementariness of linguistic scholarship and vernacular humanism as one of the means by which mid-twentieth-century Scottish Renaissance writers could, through translation, as in Young's Aristophanic translations, exercise and elaborate the resources of Scots and thereby demonstrate the language's expressive powers.

The promotion through translation of Scots - or of «Lallans », his preferred term - was for Young part of a larger agenda in relation to the language. In J.D. McClure's words, Young was «aiming, from motives as much political as literary, to devise a national language based on vernacular speech which would compete with the dominant lingua franca ${ }^{20}{ }$. There is ample evidence of this in statements by him, as in these two separate examples:

[The] national status of Lallans must be emphasised, if only because so many superficial readers or propagandist hacks have dubbed it a mere dialect of English, a provincial variant of the King's English.

Lallans is a language of a nation, Hugh MacDiarmid and others are restoring it in full vigour for all the purposes of national selfexpression [...] After prolonged coma, Scotland is waking up, and the Renaissance in Lallans is [...] one manifestation of this process $^{21}$.

We see here the coming together of two of the elements that MacDiarmid defined as key features of the Scottish Renaissance, namely, «a revived Scottish Nationalism» and «a new insistence on the Scots language». The linguistic politics that flowed from this required strategies for both the practice and the propagandising of writing in Scots. As regards practice, as has already been noted, it had to be demonstrated through original writing of ambitious range, and through translations of high literature, that Scots had the capacity to be considered

20. McGlure, «Three Translations by Douglas Young», p. 198.

21. Douglas Young,

«Plastic Scots» and the Scottish Literary Tradition: An authoritative introduction to a controvers [?Glasgow:? William MacLellan,? 1947], p. 3,31 . a «language»; or at least, a «language-in waiting». Also, methods for expanding the resources of Scots and asserting its distinctiveness had to be developed. The political dimension to the nature of the practice flowing from this, as indicated by that italicising, can be illustrated by a statement by Young such as the following: 
If Lallans fails, coin something from Latin or Greek if you like, as King's English does; if all else fails admit a Hottentotism rather than another Anglicism. This should be our intransigent policy for the next five hundred years or so $^{22}$.

At other times his position is less inflexible:

I approve the principle of taking in a good English word if it expresses a concept or shade of meaning for which there is no Lallans word, just as English admits French words like «Chic» or Urdu terms like «Pukka». But we must be canny about this and not take in an undue share of Anglicisms. (Puddocks, p. vi \& Burdies, p. v)

But whatever the shifting tone that we find in these and similar statements by Young, the political stance informing his viewpoint on evolving Lallans as a national language is transparent.

As regards his propagandising on behalf of Lallans, he pursued this through public lectures, articles, and pamphlets such as «Plastic Scots» and the Scottish Literary Tradition (1946) and The Use of Scots for Prose (1949) - both based on public lectures, with the former, significantly, chaired by Hugh MacDiarmid (Young, 1949). Another arm of his activism was his «language planning» activities, as in the instrumental part he played in drawing up in 1947, under the aegis of the Makkars' Club in Edinburgh, the «Scots Style Sheet», comprising recommendations for the standardisation of Scots spelling. One reason for his concern here related to the parlous contemporary state of Scots:

What we should realise, I think, is that there is today a crisis for the Scots tongue. [...] it cannot be denied that it is more and more being relegated to the position of a dialect, or series of patois, whose literary value is confined to the comic or the sentimental. With the influence of the English wireless and the American cinema we shall require a good deal of vigilance and effort to maintain the old speech in anything like its integrity. One part of that effort must, I submit, be directed to prose. (Young, 1949, p. 19)

22. (Young, "Plastic Scots...»., p. 23.). Corbett (1999, p. 159), judges that the "linguistic exclusivism» demonstrated in this statement «smacks of the unsavoury side of nationalism».
Because of the loss of a formal prose register for Scots in the seventeenth century, from when, he said, «dates the confused and unrealistic orthography of Lallans » (Plastic Scots, p. 12), any attempted recreation of a Scots prose would require a settled spelling system for the benefit of writers and readers. As he saw it, this, too, had a political dimension: 
Supposing it be desired to develop the potentialities of Scots for prose as an independent literary medium, as distinct from English as it is from German or Norwegian, can it still be done, and if so how? [...] It is partly a political question, language being in large measure a political instrument. (Young, 1949, p. 17)

He argued that one of the ways in which a prose could be developed was through translation, which he considered to be «indispensable» for advancing Scots (Young, 1949, p. 19). Indeed, he called for a society to be formed « $[\mathrm{t}] \mathrm{o}$ sponsor and subsidise translations into Scots», and suggested that an organisation such as the Saltire Society or the Burns Federation might sponsor «a series of translations ${ }^{23}$ ». It can therefore be claimed that his translation of drama, like his translation of poetry and his call for translation of prose, can be placed within the larger context of a strategy to extend the literary range of Scots and thereby contribute to enhancing its status culturally, socially, and politically. Prose and play translations in turn would sit alongside original writing where, in his words, «the theatre and other media will be carrying into daily life and journalism and prose literature the work done in Lallans verse». (Plastic Scots, p. 32). Of plays in particular, he stated approvingly in 1947, in an article written in Scots, "Robert Kemp and Robert Maclellan hae shawn what can be duin wi Lallans in stage-plays, whaur dialogue whiles gangs aff intil extendit discourse that comes near a richt prose ${ }^{24} »$. He explicitly related all of this to what he called MacDiarmid's «propaganda for a Scottish Renaissance» when, in 1952, in enumerating his mentor's aims, he gave as «first, the extended use of the distinctive national languages, Lallans and Gaelic, not only for verse but also for drama and prose and all the purposes of discourse ${ }^{25}$ ». One notes here the recurring references to the importance of work for the stage as a key part of a wider programme for advancing the status and capacities of Scots.

23. Loc cit.

24. Douglas Young, «Thochts Anent Lallans Prose ", The Scots Review 8:1, April 1947, p. 14. 25. «Foreword by Douglas Young », in Scottish Verse 1851-1951, selected by Douglas Young, London, Thomas Nelson, 1952, p. xxvixxvii.
In sum, then, and returning to Young's motivation specifically in translating The Puddocks and The Burdies, the foregoing allows one to argue with confidence that informing factors included his politico-cultural nationalism and his close identification with the ideals of the twentieth-century Scottish Renaissance, particularly as regards promotion of Scots to national status. Achievement of the latter entailed application of his linguistic erudition in extending the reach of Scots, and 
included in the strategy for so doing was the revival of a translation tradition inspired by a historical awareness of Scottish humanism and an internationalism of outlook. These shaping considerations are confirmed in Young's own formulation of the common motivation behind his and his fellow Scottish Renaissance writers'efforts: "[We] share a desire to reestablish the cultural contacts of Lallans with other literatures which the English predominance had occluded, and to retrieve, refine, and extend Lallans as a national language fit for all purposes of verse, and indeed of literature generally» (Plastic Scots, p. 19).

That quotation, with its reference to retrieval, refinement and extension of Lallans, provides a pointer to Young's method in his use of Scots in striving for an aggrandised medium that was, in his words, capable of «amplitude and exaltation " (Plastic Scots, p. 15). However, although he numbered himself among those Scottish Renaissance writers whom he described as «full-canon Lallanders» (Plastic Scots, p. 17), he was aware, as evidenced by his translations of Aristophanes, that there was a risk attached to an overly-scholarly and over-literary approach to creating a synthetic Scots whose focus was primarily poetry:

[G] in Lallans verse-makin isna tae be an academic dilettante ploy like Greek elegiacs or Latin hexameters, the «Plastic» Makars maun uis the leid for ither purposes than poetry, namely for prose and for speakin. Itherweys the vitality o the leid maun be tint $^{26}$.

Drama, as a quintessentially speech-based genre, was a means by which «the vitality o the leid» could be exercised and demonstrated. One can find in many of Young's statements a tension between concepts of «good» and «bad» Scots ${ }^{27}$, particularly in relation to colloquial contemporary urban Scots, that might be thought to militate against this. Just the same, the

26. "Thochts Anent Lallans Prose», p. 14. 27. These terms are coined and defined in A.J. Aitken, «The Good Old Scots Tongue: Does Scots have an Identity?» (Haugen, 1981, p. 8586). An example of Young's dismissal of what he calls there "debased patois of Scots» is reprinted in A Clear Voice, p. 82.
Scots in The Puddocks and The Burdies is generally less densely synthetic and more vernacular in nature than is the case with most of his poetry and translated poetry. This does not negate problems of intelligibility for an audience, as confirmed by the controversy centred on that issue that surrounded the 1966 production of The Burdies at the Edinburgh International Festival (Young, 1966). But, as that translation shows, the hybrid Greek-Scots world he created, with its topical allusions to Scottish life, from Celtic and Rangers to razor gangs to the 
Edinburgh Military Tattoo, and his hybridising employment of contemporary Scottish, English and American usages, together betray a less principled and more pragmatic stance than might be judged from some of his severer statements on language and culture such as those instanced earlier in relation to his motivation. The same more relaxed attitude may be seen in the leeway on performance language he proffers with The Puddocks: «producers have my entire goodwill in discreetly watering down my Scots reading version with whatever English, American, Irish, or other expressions they may think proper to their purpose» (Puddocks, p. ix). This is one reason why his play translations are of particular interest, as study of them, and the link between motivation and mode of medium, offers a corrective to the impression of a more puristic stance on Scots than his reputation to date, based on his other work, suggests. What such study also does, from the perspective of Scottish theatre, is to highlight that his mode of approach in The Puddocks and The Burdies - in juggling many varieties of register and fashioning an experimental «stage-

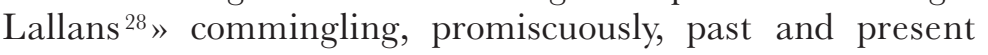
usages, and contemporary anglicisms and Americanisms (contradicting his earlier-quoted wish to reject such imports) - foreshadowed by almost three decades, as an exemplar-inprinciple, the individualistic theatrical Scots that characterises Liz Lochhead's Tartuffe and Edwin Morgan's Cyrano de Bergerac ${ }^{29}$. This is further reason why Young's achievement

28. The term «stageLallans» is borrowe from John Corbett (1999, p. 155), where it is specifically applied to Young's translation of Aristophanes.

29. For discussion of these and other aspects of Young's use of Scots in The Puddocks and The Burdies, see Bill Findlay, «Motivation and method in Scots translations, versions, and adaptations of plays from the historic repertoire of continental European drama", unpublished doctoral thesis, 2 vols., Queen Margaret University College, Edinburgh, 2000, vol. I, chap. 4 . with his Aristophanic translations is deserving of greater attention.

\section{Bibliography}

Corbett J., Written in the Language of the Scottish Nation: A History of Literary Translation into Scots, Clevedon, Multilingual Matters, 1999.

Craig C. ed., The History of Scottish Literature, vol. 4, Twentieth Century, Aberdeen, Aberdeen University Press, 1987.

Dunlop B., Klytemnestra's Bairns, Edinburgh, Diehard, 1993.

Findlay B. ed., Frae Ither Tongues: Essays on Modern Translations into Scots, Clevedon, Multilingual Matters, 2004. 
Hardwick L. \& Gillespie C. eds.,The Role of Greek Drama and Poetry in Crossing and Redefining Cultural Boundaries, Milton Keynes, The Open University, 2003.

Haugen E. et al. eds., Minority Languages Today, Edinburgh, Edinburgh University Press, 1981.

Kemp R., Let Wives Tak Tent, Glasgow, Brown, Son \& Ferguson, 1983.

-, The Laird o' Grippy, Glasgow, Brown, Son \& Ferguson, 1987.

Lindsay M. ed., Poetry Scotland: Second collection, Glasgow, William MacLellan, 1945.

Lochhead L., Tartuffe: A translation into Scots from the original by Molière, Glasgow, Third Eye Centre/Polygon, 1985.

-, Medea (after Euripides, London, Nick Hern Books, 2000.

Lorimer W.L., The New Testament in Scots, Edinburgh, Southside, 1983.

Macafee C. and Macleod I. eds., The Nuttis Schell: Essays on the Scots language, Aberdeen, Aberdeen University Press, 1987.

McClure J. Derrick ed., Scotland and the Lowland Tongue, Aberdeen, Aberdeen University Press, 1983.

Morgan E., Edmond Rostand's Cyrano de Bergerac, Manchester, Carcanet, 1992.

Racine J., Phaedra: Translated from French into Scots by Edwin Morgan, Manchester, Carcanet, 2000.

Sutherland R.G. [a.k.a. Robert Garioch], George Buchanan's Jepthah and The Baptist translatit frae Latin in Scots, Edinburgh, Oliver and Boyd, 1959.

Wittig K., The Scottish Tradition in Literature, Edinburgh, Oliver and Boyd, 1958.

Young D., Auntran Blads, Glasgow, William MacLellan, 1943.

-, A Braird o Thristles, Glasgow, William MacLellan, 1947.

-, «The Use of Scots for Prose» being The John Galt Lecture for 1949, Greenock, Greenock Philosophical Society, 1949.

-, Chasing an Ancient Greek: Discursive reminiscences of an European journey, London, Hollis \& Carter, 1950.

-, The Puddocks: A Verse Play in Scots from the Greek of Aristophanes, 2nd ed., Tayport, The author, 1958.

-, The Burdies: A Comedy in Scots Verse from the Greek of Aristophanes, 1st ed, Tayport, The author, 1959.

-, Scots Burds and Edinburgh Reviewers: A Case Study in Theatre Critics and Their Contradictions, Edinburgh, Macdonald, 1966. 